\title{
The north Brazil undercurrent and the wind driven hydrodynamics in Japaratuba submarine canyon, Brazil
}

\author{
Sergio Rafael Del-Giovannino ${ }^{1} \mathbb{C}^{0}$, Marcelo Dottori $^{1 *}$, Renato Parkinson Martins $^{2}$
}

\author{
${ }^{1}$ Instituto Oceanográfico da Universidade de São Paulo, Departamento de Oceanografia Física \\ (Praça do Oceanográfico, 191 - Cidade Universitária - Butantã - São Paulo - 05508120 - SP - Brazil) \\ ${ }^{2}$ Petrobras, Centro de Pesquisas Leopoldo Américo Miguez de Mello (CENPES) \\ (Av. Horácio Macedo, 950 - Cidade Universitária da Universidade Federal do Rio de Janeiro, Rio de Janeiro - 21941-915 - RJ - Brazil) \\ *Corresponding author: mdottori@usp.br
}

\section{ABstract}

The circulation induced by the wind and the North Brazil Undercurrent (NBU) in and surrounding the Japaratuba submarine canyon on the continental shelf of the basin of Sergipe and Alagoas is described using numerical modeling. The numerical simulations were implemented to determine the canyon influence in the local hydrodynamics and in the volume flow normal to the coast, considering several different scenarios, including a homogeneous and stratified fields of temperature and salinity. Northeast and East winds favor an upward flow in the canyon, while Southeast and South winds privilege subsidence. Winds parallel to the coast cause greater volume flow in the canyon section: $40^{\circ}$ winds (relative to true the North, parallel to the coast) caused the highest upward flow, while winds from $215^{\circ}$ to $220^{\circ}$ caused the highest subsidence. On the other hand, the NBU favors subsidence motion and seems to predominate over the wind forcing.

Descriptors: Japaratuba submarine canyon, Wind-driven flow, North Brazil Undercurrent, Numerical modeling.

\section{INTRODUCTION}

Sergipe and Alagoas are two states located in the northeast Brazil region bathed by the Atlantic Ocean at relatively low latitudes, between $9^{\circ} \mathrm{S}$ and $11^{\circ} 30^{\prime} \mathrm{S}$ (Figure 1). Their continental shelf (SEALCS) extends for $370 \mathrm{~km}$, with an orientation of approximately $40^{\circ}$ clockwise relative to the geographic North, and is a narrow region, with a width varying from $18 \mathrm{~km}$ in the south, to 42 $\mathrm{km}$, in front of Maceio (Coutinho, 1976; Summerhayes et al., 1976). At the slope of the Sergipe-Alagoas margin runs the North Brazil Undercurrent, a western boundary current that transports more than $20 \mathrm{~Sv}$ in the first $1000 \mathrm{~m}$, and with a core at subsurface levels, between 100 and $200 \mathrm{~m}$ deep (Silveira et al., 1994; Stramma et al., 1995).

Submitted on: 26/September/2018

Approved on: 12/June/2019

http://dx.doi.org/10.1590/S1679-87592019022106702
The SEALCS is relatively shallow, rarely exceeding $50 \mathrm{~m}$ of depth, and is characterized by the presence of the Sao Francisco river, dividing the states, and the presence of the Sao Francisco and Japaratuba submarine canyons, crossing normally the platform and the slope. The currents over the shelf are driven during most of the time by the winds, with the Sao Francisco river discharge and tides playing a relatively small role (Parente, 2016).

The Sao Francisco canyon is located close to the river of the same name, with an entrance of $11 \mathrm{~km}$ wide and 700 $\mathrm{m}$ deep, starting from the $15 \mathrm{~m}$ isobath. The Japaratuba canyon is located south of the Sao Francisco canyon, close to the Sergipe river, with an entrance of $21 \mathrm{~km}$ and depths that reach more than $1400 \mathrm{~m}$, from the $30 \mathrm{~m}$ isobath (Coutinho, 1976; Summerhayes et al., 1976). Figure 1 shows the locations of the canyons and the Sao Francisco river. 


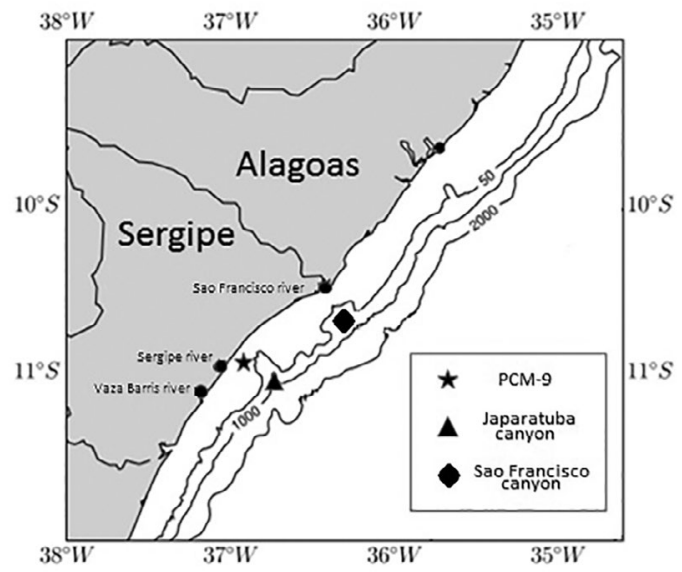

Figure 1. The Sergipe and Alagoas Continental Shelf with the 50, 1000 and $2000 \mathrm{~m}$ isobaths. The locations of the Japaratuba and Sao Francisco submarine canyons, the river discharge locations, the Sao Francisco, Vaza Barris and Sergipe rivers, and the location of the PCM-9 platform are also represented.

Basically, in continental shelf regions, the currents are predominantly parallel to the coast. Because they are mainly in geostrophic equilibrium, they tend to follow isobaths, being able to cross smooth variations of bathymetry. This prevents large flows perpendicular to the coast, between the continental shelf and the deep ocean (Freeland and Denman, 1982; Sobarzo et al., 2001; Skliris et al., 2002; Song and Chao, 2004). However, when the currents approach narrow canyons, the flow crosses isobaths and the column stretches, altering the vorticity. In this situation, the free surface of the ocean rises and produces pressure gradient in the canyon, which induces water flow along its axis. Thus, the pressure gradient in the canyon is not balanced by the Coriolis force and the circulation is no longer geostrophic (Freeland and Denman, 1982; Klinck, 1988, 1996; Allen, 1996; She and Klinck, 2000).

When it ceases to be geostrophic, the circulation presents acceleration, which can only be balanced by the friction and will cause flows perpendicular to the coast along the axis of the canyon, leading to subsidence or resurgence (Freeland and Denman, 1982; Allen et al., 2001). Thus, the topography of submarine canyons makes them preferential paths of mass exchange between the continental shelf and the deep ocean.

For instance, Hamilton et al. (2015) concluded, by numerical simulation, that in the De Soto Canyon, in the Gulf of Mexico, there is a mass transport crossing isobaths, with mass export from the canyon larger than the import. Ahumada-Sempoal et al. (2015) studied water and particles transport in the Canyons of Balnes (Mediterranean Sea) using climatological simulation, and concluded that the mass export from the continental shelf to the slope is 3 times greater than the import, and the transport along the isobaths is one order of magnitude greater in the canyon than in adjacent regions.

Skliris et al. (2002) carried out simulations for the Calvi canyon, in Corsica (Mediterranean Sea), for different stratification regimes and wind patterns. These authors concluded that the transport along the canyon is reduced under conditions of greater stratification and that the wind strongly influences the cross-shore transport. Rennie et al. (2009) have shown that in the canyon of Perth (Australia) there is a recurrent formation of cyclonic and anti-cyclonic vortices within the canyon and that the resurgence in it was more intense than at any other site on the continental shelf.

Canyons also affect local circulation and hydrodynamic conditions, as well as being regions that can increase productivity (Madron, 1994; Bosley et al., 2004; Skliris et al., 2004; Rennie et al., 2009).

In situ data, laboratory experiments and results from numerical models suggest that the direction of the currents parallel to the coast determines if the canyon favors conditions of resurgence or subsidence (Freeland and Denman, 1982; Hickey et al., 1986; Klinck, 1988, 1996; She and Klinck, 2000; Skliris et al., 2002; Bosley et al., 2004; Jordi et al., 2005; Palanques et al., 2005; Rennie et al., 2009).

Generally, flows that are parallel to the coast but in the opposite direction of the Kelvin Waves propagation are associated with upwelling processes (upward and towards the coast) and flows that are in the same direction as the propagation of Kelvin waves favor downwelling processes (downward flow and towards the ocean) (Klinck, 1996; Hickey, 1997; Ardhuin et al., 1999; She and Klinck, 2000; Allen et al., 2001; Allen and Madron, 2009). Basically, upwelling processes are associated with a decrease in the sea level at the coast, creating a barotropic pressure gradient towards the coast and the canyon enhances this dynamics. Subsidence processes occur in opposite conditions, i.e., an increase in the sea level at the coast with a consequent pressure gradient towards offshore.

Several studies coincide with this pattern, such as those performed in the canyons of Grand-Rhône (France) (Madron, 1994), Blanes (Spain) (Granata et al., 1999), Barkley (USA) (Allen et al., 2001), Biobío (Chile) (Sobarzo et al., 2001), Calvi (France) (Skliris et al., 2002), Astoria (USA) (Bosley et al., 2004) and Palamós (Spain) 
(Jordi et al., 2005). Numerical simulations also find the same behavior, like in the studies of Astoria (USA) (Hickey, 1997; She and Klinck, 2000), Blanes (Spain) (Ardhuin et al., 1999; Allen et al., 2001), Calvi (France) (Skliris et al., 2004) and Perth (Australia) (Rennie et al., 2009).

In this way, we can say that for the Southern Hemisphere, flows that leave the coast to its left would favor subsidence, while flows with the coast to its right, upward motion processes.

Therefore, similar to these studies, it is expected that these canyons promote some impact over the hydrodynamics of the SEALCS, mainly regarding the exchange of mass between the continental shelf and the deep ocean at the Japaratuba canyon, due its dimensions both horizontal and vertical. Thus, this work intends to describe, through numerical modeling, how the circulation within the Japaratuba canyon is affected by the winds and the flow of the North Brazil Undercurrent (NBU).

In the next section the numerical model and the data used are described. Section 3 presents the results followed by a discussion in Section 4. Finally, concluding remarks are presented in Section 5.

\section{MATERIAL AND METHODS}

\section{NUMERICAL MODEL}

The hydrostatic model of primitive equations Estuarine and Coastal Ocean Model (ECOM), derived from the
Princeton Ocean Model (POM) (Blumberg and Mellor, 1987), was used in this work, in the shallow water module (Blumberg et al., 1999). This is a free surface and vertical sigma coordinate model with Arakawa C-grid discretization scheme.

The grid is regular and tilted in order to align with the coastline direction and uses 50 points perpendicular to the coast by 150 points parallel to the coast, with 30 sigma levels, equally spaced. The horizontal resolution is about $2.1 \mathrm{~km}$ in the cross-shore direction, and $2.7 \mathrm{~km}$ alongshore, between the latitudes of $9^{\circ} \mathrm{S}$ and $12.2^{\circ} \mathrm{S}$, and between the longitudes of $34.6^{\circ} \mathrm{W}$ and $37.5^{\circ} \mathrm{W}$ (Figure 2 ).

Since the purpose of the simulations is to evaluate the influence of each forcing (the NBU and wind currents) separately and their interactions, 3 different types of simulations were performed. The first set of simulations were forced only by the wind stress. In this case, the temperature and salinity fields are homogeneous over the whole domain and constant in time, both as initial and boundary conditions, with temperature of $27^{\circ} \mathrm{C}$ and salinity of 37 . Also, the radiative boundary condition of Reid and Bodine (1968) is applied. A second set of experiments used stratified temperature and salinity initial conditions, as well as the sea-level, velocity, temperature and salinity prescribed at the boundaries. In this case, only the NBU is created. Finally, a third set of simulations included the wind stress at the surface, and stratified fields of temperature and salinity, so the NBU and the wind forcing interact.

It is important to mention that all simulations were warmed-up for 15 days, a period that was not analyzed,

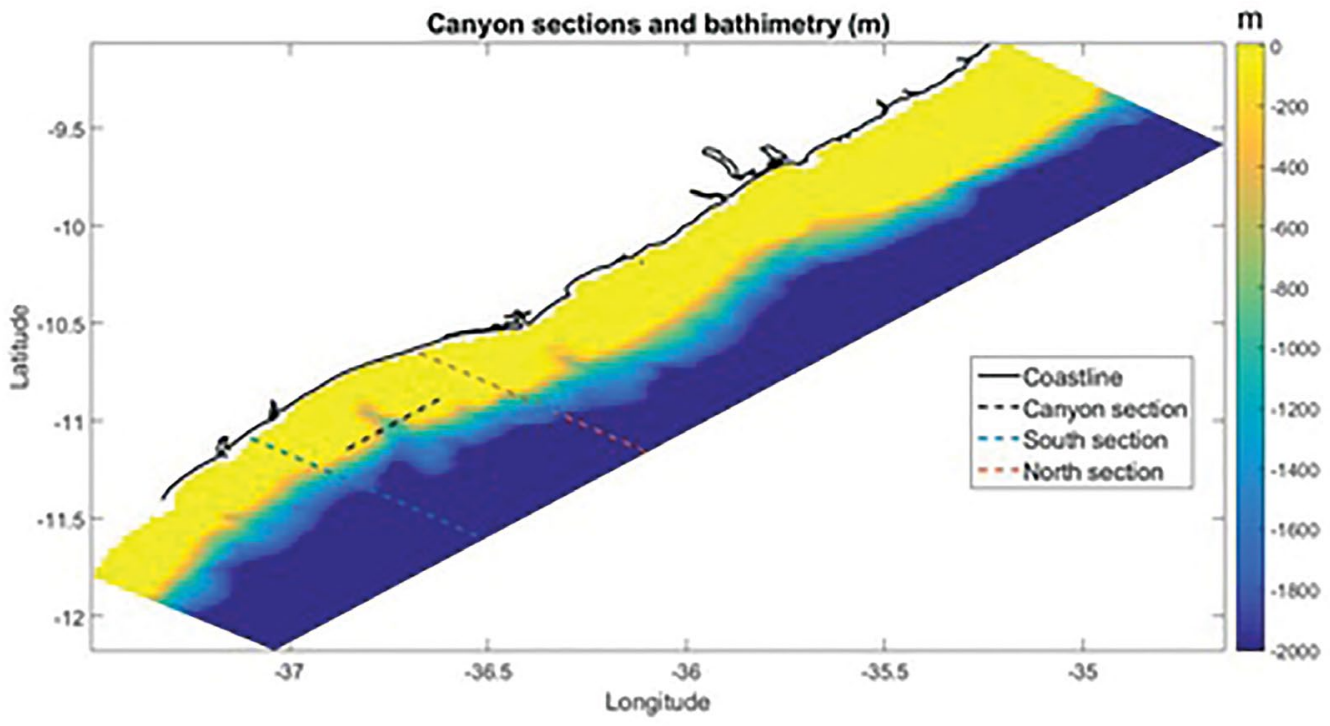

Figure 2. Domain of the numerical model with the local bathymetry. The dashed lines indicate the 3 sections near the Japaratuba canyon, one parallel to the coast and 2 others at the south and north borders of the canyon, in the cross-shore direction. 
and run for more 30 days, performing a total of 45 days of integration. The 15-day warm-up period was enough to have the dynamics fully developed, since all simulations presented a period of about 12 days to stabilize the mechanic energy in the domain. More details about the set-up for the simulations as well as the model validation are in Parente (2016).

\section{DATA}

The Regional Characterization Project of the SergipeAlagoas basin (PCR-SEAL), funded by PETROBRAS, the Brazilian oil company, provided hourly wind records that were used to run the simulations. These time series were obtained with a Young Meteorological Station at the oil platform PCM-9 (Figure 1), located at 1059'12"S and 36 56'53"W, between March 9, 2012 and December 31, 2014. The wind directions presented in Figure 3 show that the wind comes mainly from the east and southeast directions, but with a direction range that varies from south to northeast directions.

The National Centers for Environmental Prediction (NCEP) provided the wind data set (CFSV2; Saha et al., 2014) used to run more realistic simulations for the months of March, July and September 2014. The 6-hour interval time series were used to run the simulations by interpolating the CFSV2 wind to the grid of the model. These specific months were chosen because a previous validation of these periods were performed for the continental shelf with good agreement by Parente (2016). Also, these different months provide a good wind variability. These data sets can be downloaded at http://www.ncep.noaa.gov/.

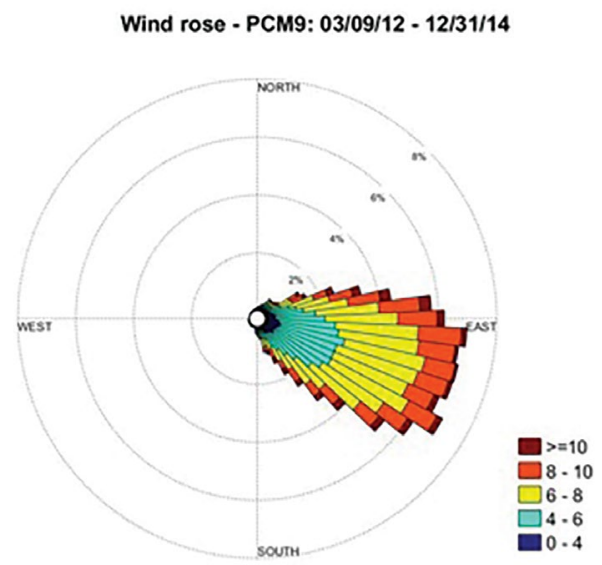

Figure 3. Wind rose representing the time series of the wind from March 9, 2012 until December 12, 2014, in the oil platform PCM-9. The wind velocity is in $\mathrm{m} . \mathrm{s}^{-1}$. The wind rose was created using the original data without any filtering process.
The local bathymetry was obtained through digitized nautical charts provided by the Hydrographic and Navigation Department (DHN) of the Brazilian Navy and are also described in Parente (2016).

Finally, the monthly average temperature and salinity fields used as initial and boundary conditions and current at the boundaries were obtained from the Mercator global simulations (Lellouche et al., 2016). The main reason to use these data sets instead of climatological records is to make the interior of the domain compatible with the boundaries, avoiding inconsistencies or discontinuities during the simulations.

\section{SimULATED SCENARIOS}

Initially, constant spatial and temporal winds from Northeast, East, Southeast and South directions in homogeneous temperature and salinity fields simulations were performed. These wind directions are chosen for being the extreme (NE and S) and the most common ones (E and $\mathrm{SE})$. The second set of simulations kept the same wind directions, but in stratified fields of temperature and salinity from the Mercator output average of September 2014. A single simulation with null wind fields and temperature and salinity stratification from September 2014 was also performed, followed by simulations of reanalysis winds and stratified fields of temperature and salinity for the months of March, July and September of 2014. These scenarios are presented in Table 1.

Three different sections are used to analyze the results (Figure 2). The first section is parallel to the coast and represents the section of the Japaratuba canyon where calculations were made to estimate the volume flow of water exchanged between the canyon and the deep ocean. The other two sections are perpendicular to the coast, one to the south of the canyon and another to its north, and were made to better describe the circulation around the canyon.

The volume flow $(Q)$ in the parallel section to the coast was estimated by computing the integral of the perpendicular velocity over the are of the section.

Since the focus is on the volume flow that leaves or enters the canyon, only depths greater than $50 \mathrm{~m}$ are considered in this calculation, so the currents at the continental shelf are not accounted for. Negative values of perpendicular velocity and volume flow mean movements toward the canyon, or upward motion, while positive values indicate a canyon flow towards the open ocean, or subsidence. Upward motion is used as the opposite meaning of subsidence motion, to avoid the use of the term upwelling, since upwelling is not observed in the region. 
Table 1. Description of the scenarios simulated. For constant winds, the intensity is set to $6.5 \mathrm{~m} . \mathrm{s}^{-1}$, the average wind speed obtained at PCM-9 station (Figure 3). The month indicates the wind time series used, with a temporal resolution of 6 hours, and/or the monthly average fields of temperature and salinity from Mercator, in the year of 2014.

\begin{tabular}{lcc}
\hline Simulation name & Wind & Temperature and salinity fields \\
\hline C1 & Constant from NE & homogeneous \\
C2 & Constant from E & homogeneous \\
C3 & Constant from SE & homogeneous \\
C4 & Constant from S & September \\
C5 & Constant from NE & September \\
C6 & Constant from E & September \\
C7 & Constant from SE & September \\
C8 & Constant from S & September \\
NW & Absent & March \\
R1 & March & July \\
R2 & July & September \\
R3 & September & \\
\hline
\end{tabular}

\section{RESULTS}

The circulation in experiments $\mathrm{C} 1$ and $\mathrm{C} 2$ (constant winds from $\mathrm{NE}$ and $\mathrm{E}$ with homogeneous temperature and salinity fields), around and within the Japaratuba canyon, is quite similar. Therefore, for simplicity, the descriptions and figures presented will be only for Northeast wind. Similarly, experiments $\mathrm{C} 3$ and $\mathrm{C} 4$, (constant winds from $\mathrm{SE}$ and $\mathrm{S}$ with homogeneous temperature and salinity fields) will be discussed in terms of experiment $\mathrm{C} 3$ (Southeast winds).

Constant Northeast winds in homogeneous temperature and salinity fields (experiment C1 - Figure 4) promotes currents in the continental shelf region preferably towards southwest, ranging from 4 to $18 \mathrm{~cm} \cdot \mathrm{s}^{-1}$. In the continental slope, the current also occurs preferably towards Southwest, but not exceeding $6 \mathrm{~cm} \cdot \mathrm{s}^{-1}$ (Figure 5). At the open ocean, the currents are preferentially to Northeast and under $3 \mathrm{~cm} . \mathrm{s}^{-1}$. The major differences between experiments $\mathrm{C} 1$ and $\mathrm{C} 2$ occur in the intensity of the currents, which are slightly larger for Northeast winds. In these wind conditions, the flow along the continental slope is Southwestward, and water enters the canyon by the northernmost border (Figure 6), and rotates counterclockwise (anti-cyclonic in the Southern Hemisphere) within the canyon. A portion of this flow leaves the canyon through the southernmost border and a portion follows toward the head of the canyon.

In the vertical section of the canyon parallel to the coast (Figure 7), we can see that the volume flow occurs both from deep waters going toward the coast (negative values, Northern border) and from the coast towards the deep ocean (positive values, Southern border). The average flow in the entrance of the canyon is negative, showing a net flux of waters entering the canyon.

For Southeast winds (experiment C3), currents on the continental shelf are preferentially to Southwest, varying from 3 to $10 \mathrm{~cm} \cdot \mathrm{s}^{-1}$. At the slope (Figures 8 and 9), the currents are preferably to Northeast, under $3 \mathrm{~cm} \cdot \mathrm{s}^{-1}$. At the deep ocean, the currents flow preferentially to South and Southwest up to $100 \mathrm{~m}$ deep, and to East and Northeast below that depth, not exceeding $2 \mathrm{~cm} \cdot \mathrm{s}^{-1}$. At surface levels, a cyclonic gyre is established close to the head of the canyon, with a maximum intensity of $10 \mathrm{~cm} \cdot \mathrm{s}^{-1}$ (Figure 10) for Southeast winds. This pattern is weakened inside the canyon, with the flow entering it at the southernmost border, and leaving it at the northernmost border (Figure 11). The total volume flow in the canyon section for experiment $\mathrm{C} 3$ is positive, which means that the flow is from the canyon towards the open ocean.

Figure 12 illustrates the volume flow in the vertical section of the Japaratuba canyon calculated every $50 \mathrm{~m}$. For Northeast and East constant winds, there is a predominance of negative flows (upward motion), while for Southeast and South winds the predominance are of positive flows (subsidence motion). Therefore, between the Northeast and Southeast wind directions there is an inversion in the net volume flow in the section of the canyon.

Several other experiments were performed to find this angle of inversion or, in other words, the wind incidence angle at which the canyon changes from net exporter to net importer of water in homogeneous temperature and 

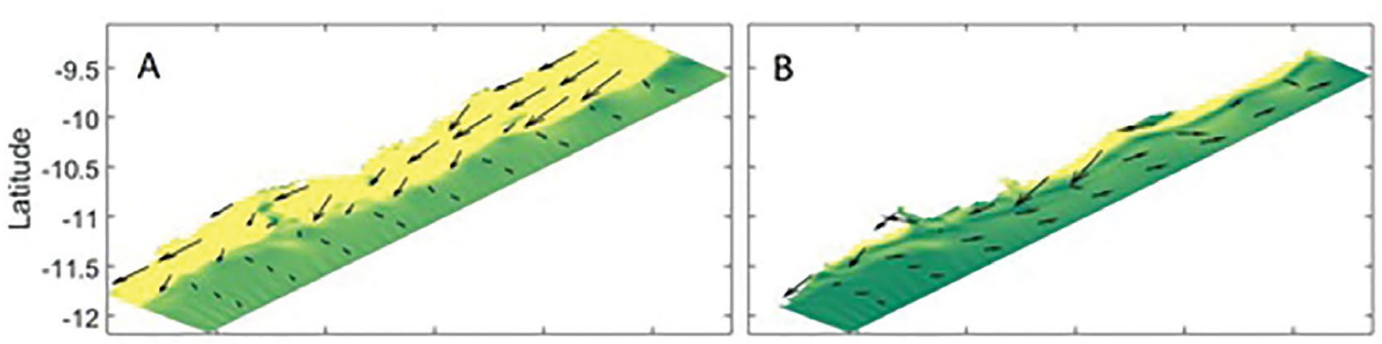

$\mathrm{m} / \mathrm{s}$
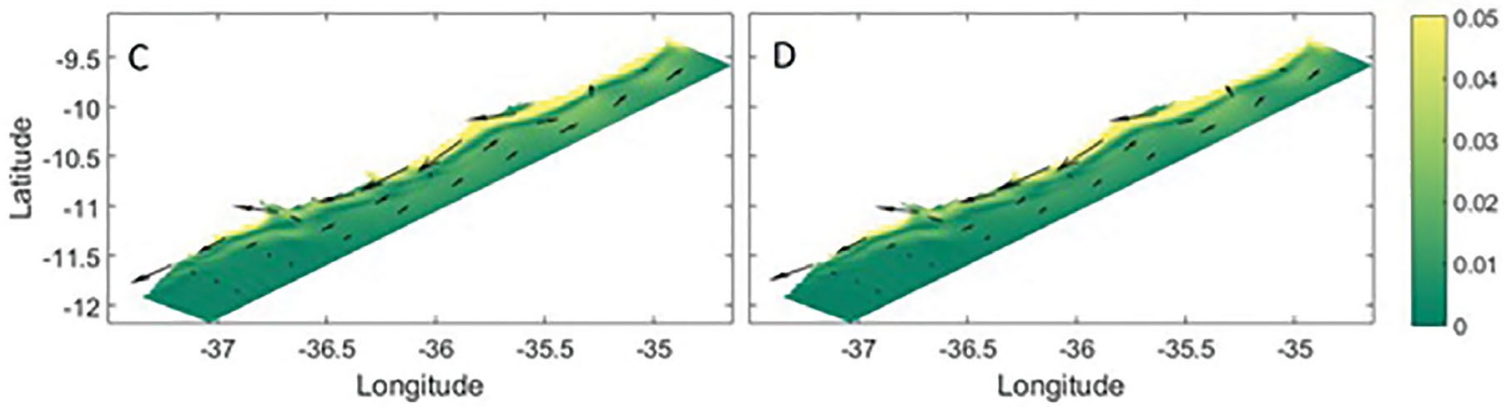

Figure 4. The velocity vectors at the depths of 10, 100, 200 and 300 meters (panels A, B, C and D, respectively), considering Northeast wind as forcing.

(a)

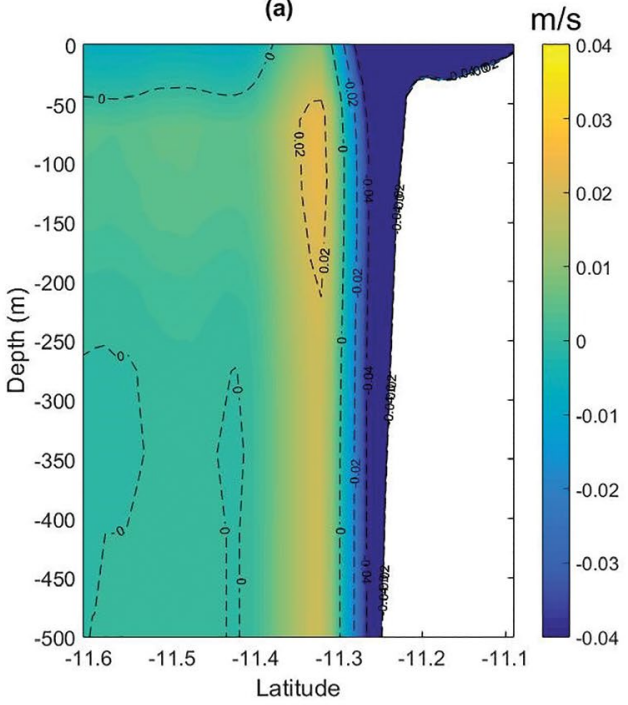

(b)

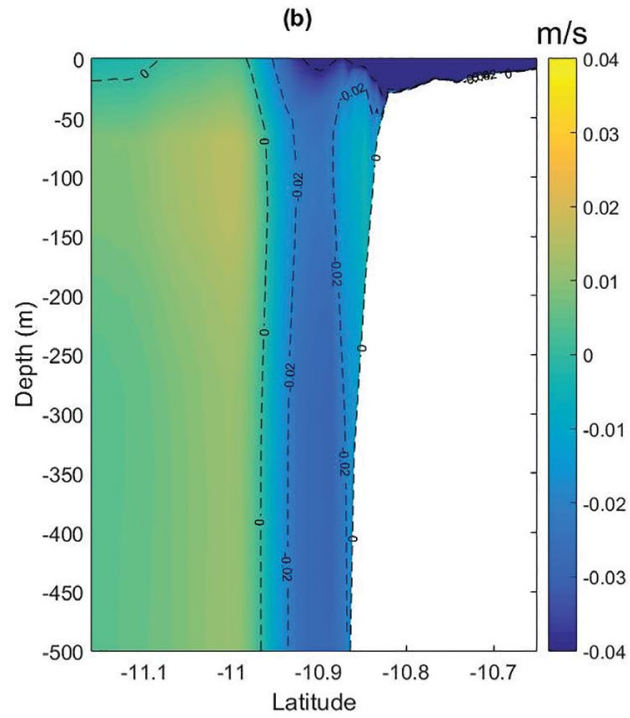

Figure 5. Velocity parallel to the coast at the South (panel A) and the North (panel B) of the Japaratuba canyon (North and South sections from Figure 2), for simulations with NE winds. Positive velocity going to NE and negative velocity going to SW

salinity fields. These simulations are not presented since they do not add more information about the canyon circulation. In any case, there is an inversion of the signal of the volume flow in the canyon for winds with angles between $120^{\circ}$ and $125^{\circ}$ in relation to the true North. Incident winds with angles smaller than $120^{\circ}$ creates a negative flow in the canyon, favoring upward motion processes, whereas for winds with an angle of incidence greater than $125^{\circ}$ relative to the true North, the flow is positive and subsidence is promoted.
It is also possible to observe that the wind direction that presented the most negative flow was $40^{\circ}$, which is the approximate orientation angle of the coast in the region. In addition, the wind direction that presented the most positive flow were between $215^{\circ}$ and $220^{\circ}$, which are almost in the opposite direction of the former. Basically, winds parallel to the coast generate the strongest flows in the canyon. 
$\mathrm{m} / \mathrm{s}$
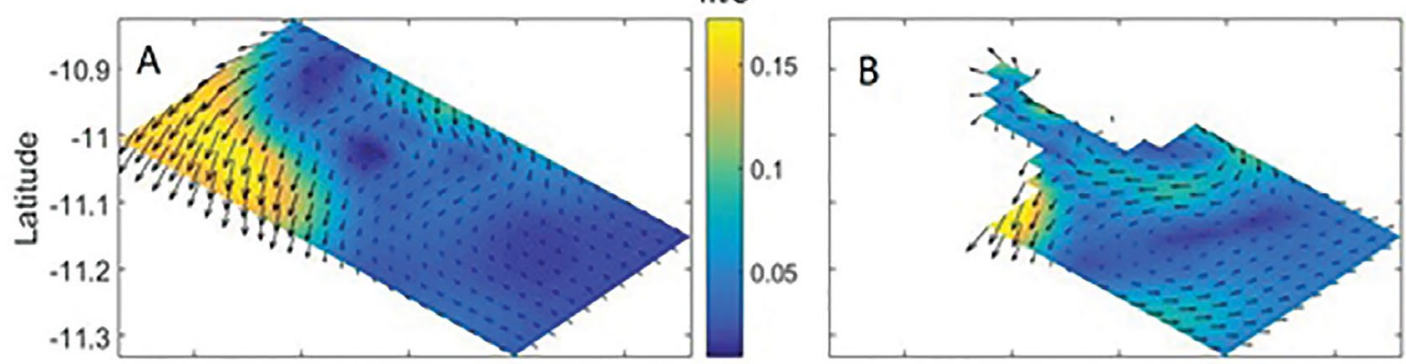

$\mathrm{m} / \mathrm{s}$
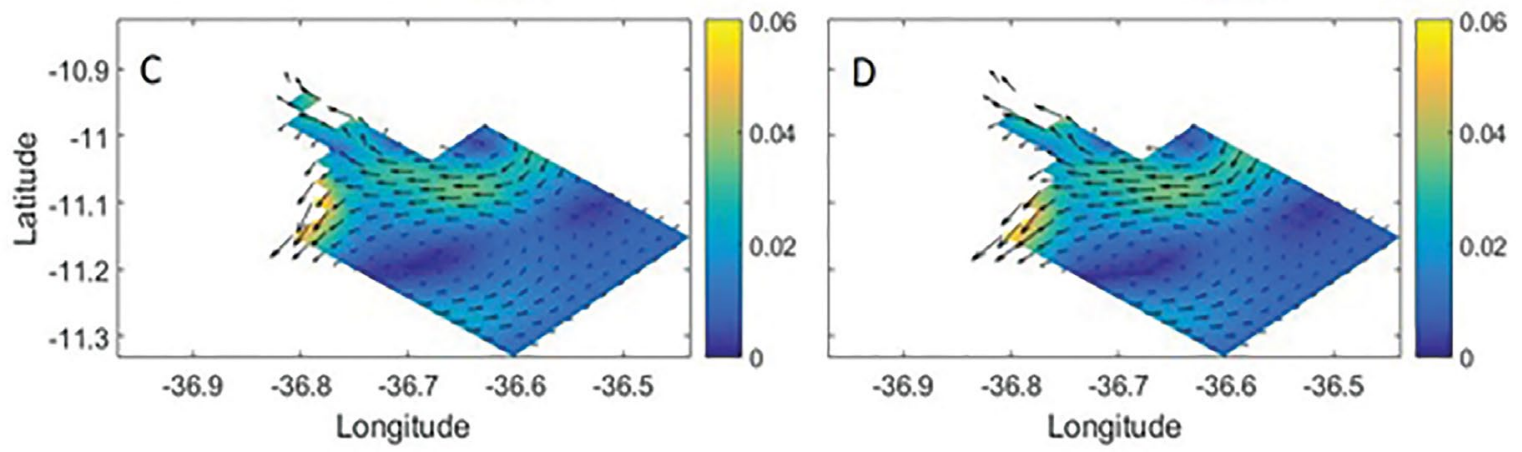

Figure 6. The velocity vectors near the Japaratuba canyon (between North and South sections from Figure 2) at the depths of 10, 100, 200 and 300 meters (panels A, B, C and D, respectively) for Northeast Wind simulation and homogeneous temperature and salinity fields (experiment C1).

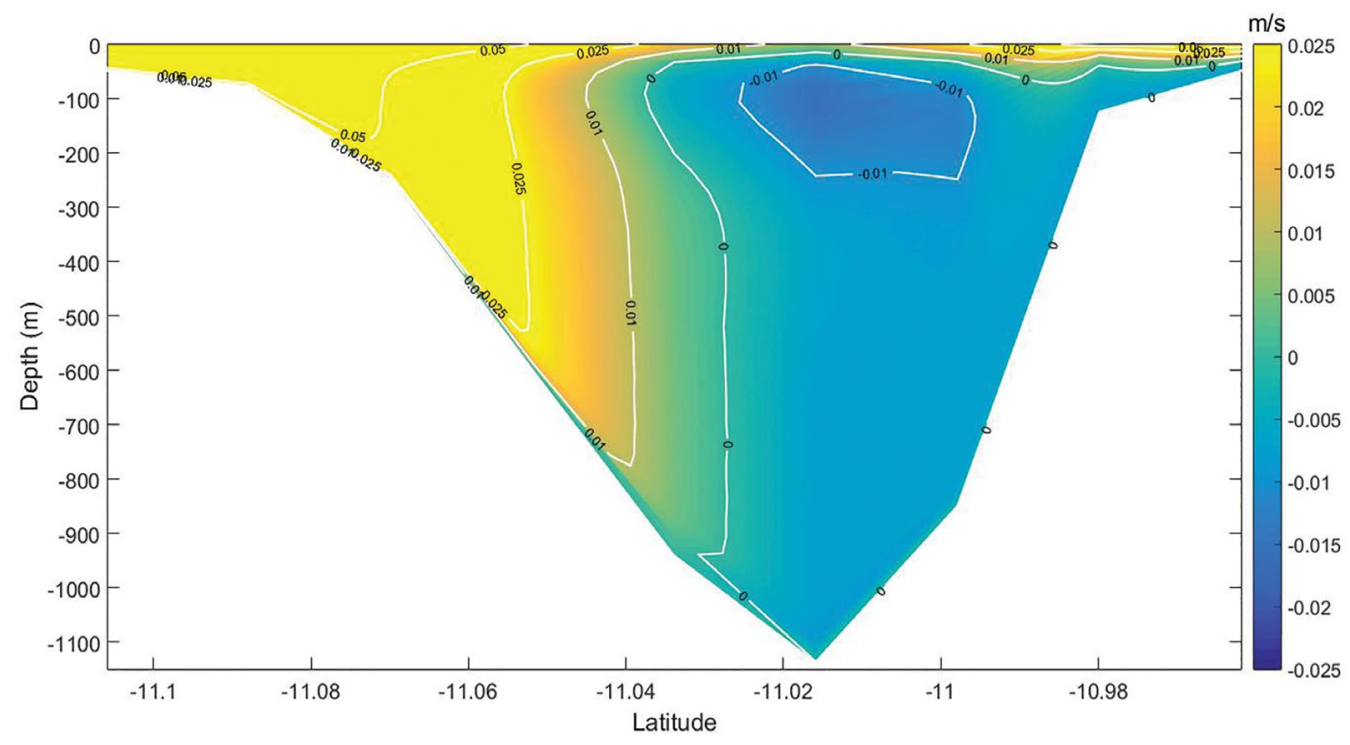

Figure 7. The velocity component perpendicular to the coast at the vertical section of the canyon (positive values indicate subsidence, negative values indicate upward motion) for Northeast wind simulation for homogeneous temperature and salinity fields (experiment C1).

When only the temperature and salinity fields from Mercator are applied, the simulations take about 12 days to stabilize. The NBU can be observed when the temperature and salinity fields of March, June and September 2014 are applied. Specifically, the conditions of September 2014 created a NBU that resembles more the classical description of this western boundary current in Silveira et al. (1994) and Stramma et al. (1995), with a core between 150 and $200 \mathrm{~m}$ of depth, maximum northeastward currents with velocities around $1 \mathrm{~m} \cdot \mathrm{s}^{-1}$ or slightly smaller and a total transport of about $20 \mathrm{~Sv}$. Therefore, and also for simplicity, the interaction between the motion generated 

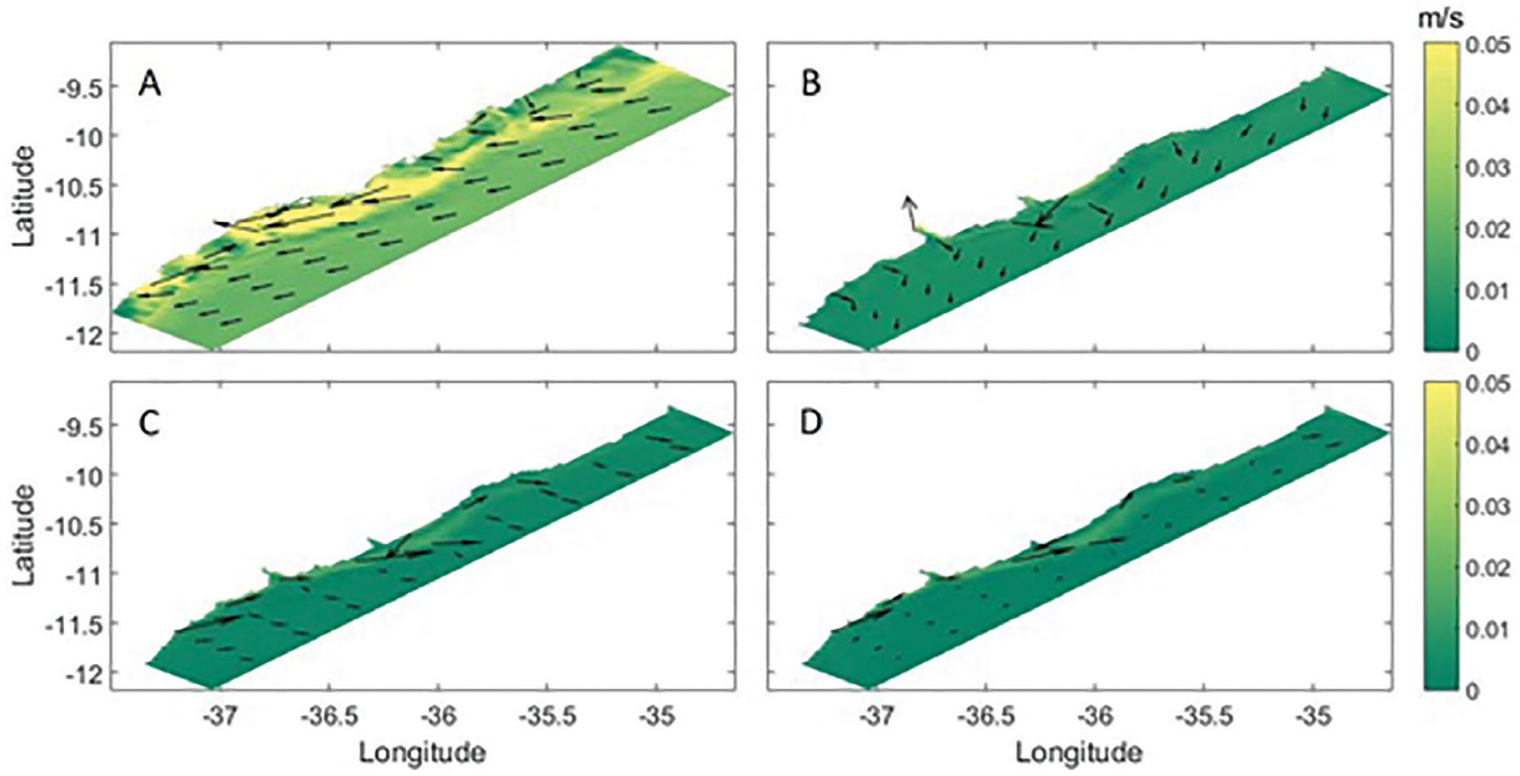

Figure 8. The velocity vectors at the depths of 10, 100, 200 and 300 meters (panels A, B, C and D, respectively), considering Southeast winds as forcing.

(a)

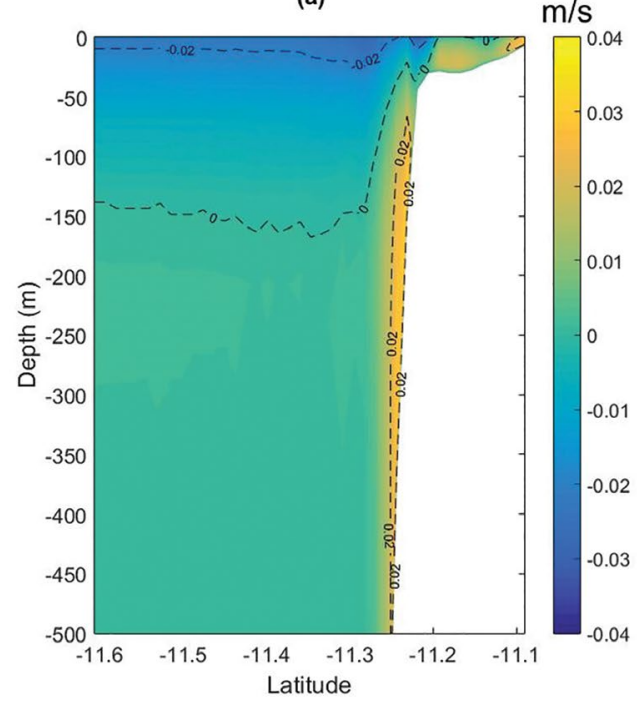

(b)

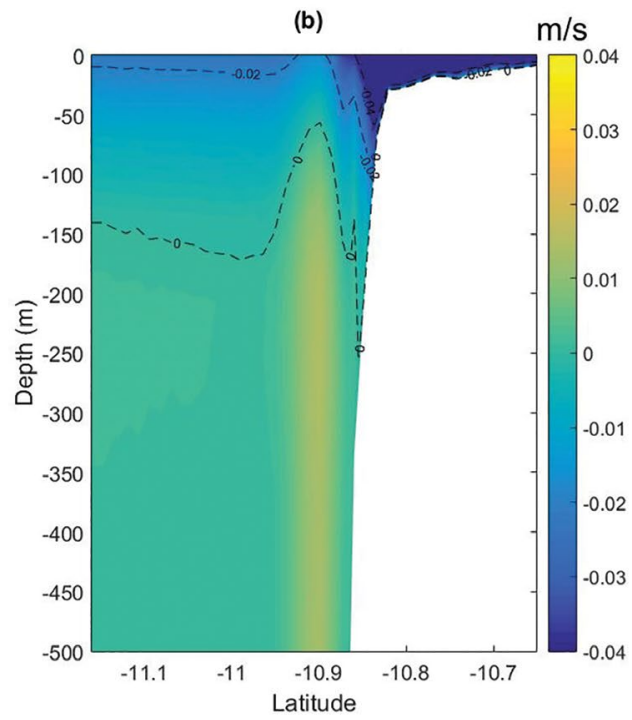

Figure 9. Velocity parallel to the South (panel A) and to the North (panel B) of the Japaratuba canyon (North and South sections from Figure 2), for simulations with SE winds. Positive velocity going to NE and negative velocity going to SW.

by constant wind forcing and the NBU (experiments C5 to C8) will be described in terms of the September 2014 temperature and salinity conditions. For the same reasons, the analysis of the circulation generated in the canyon by the NBU alone (experiment NW) will be done in terms of the September 2014 conditions as well.
Starting with experiment NW, at the shelf and in a small portion at the slope, currents are southwestward, while at the open ocean, they are northeastward. At the open ocean face of the the canyon, there is a flow from the canyon towards the deep ocean at most of the canyon, except at its center from the surface up to about $300 \mathrm{~m}$ of depth (Figure 13). The vertical 


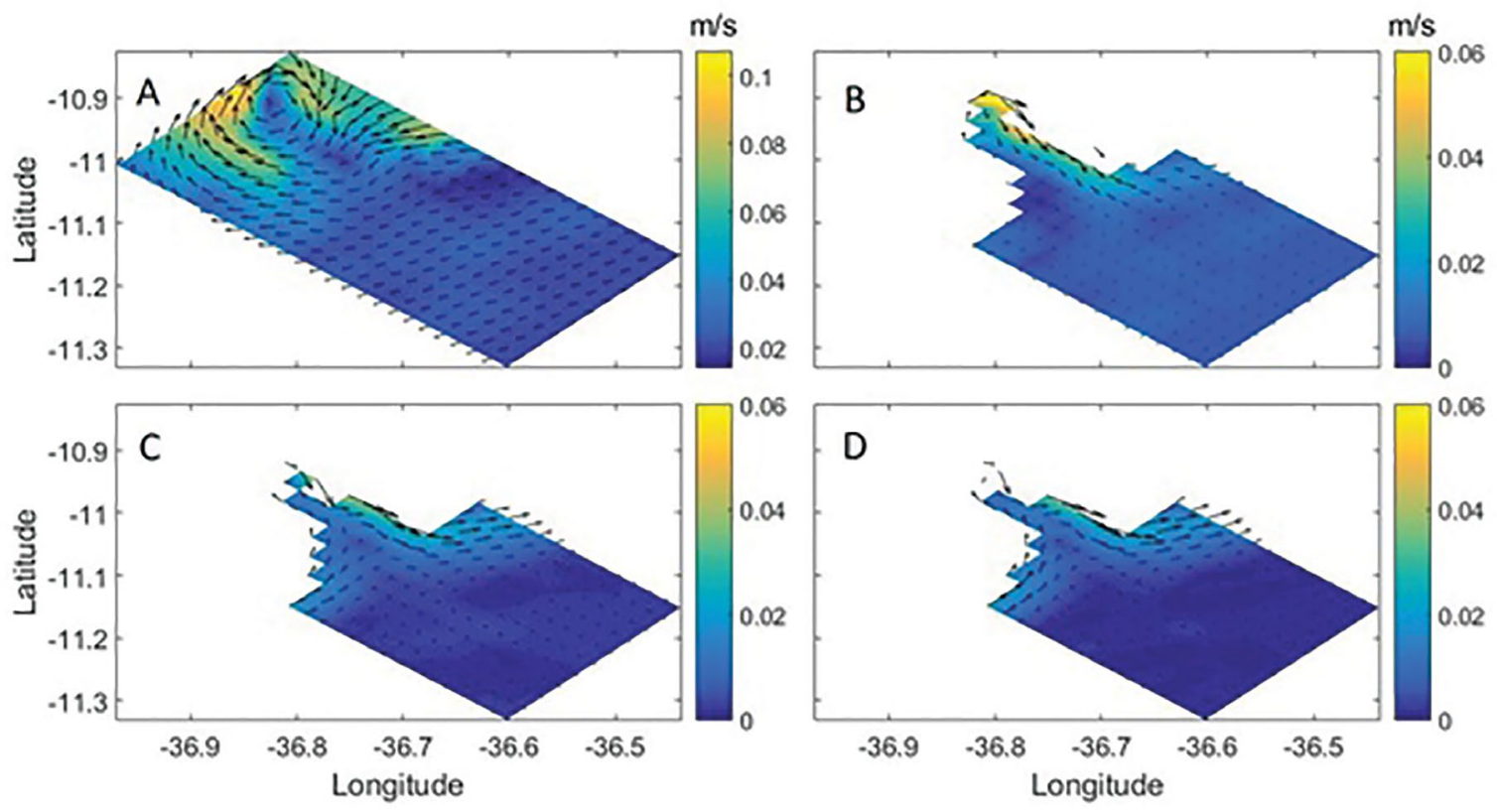

Figure 10. Circulation around Japaratuba canyon at depths (between North and South sections from Figure 2) 10, 100, 200 and 300 meters (panels A, B, C and D, respectively), for Southeast winds simulation.

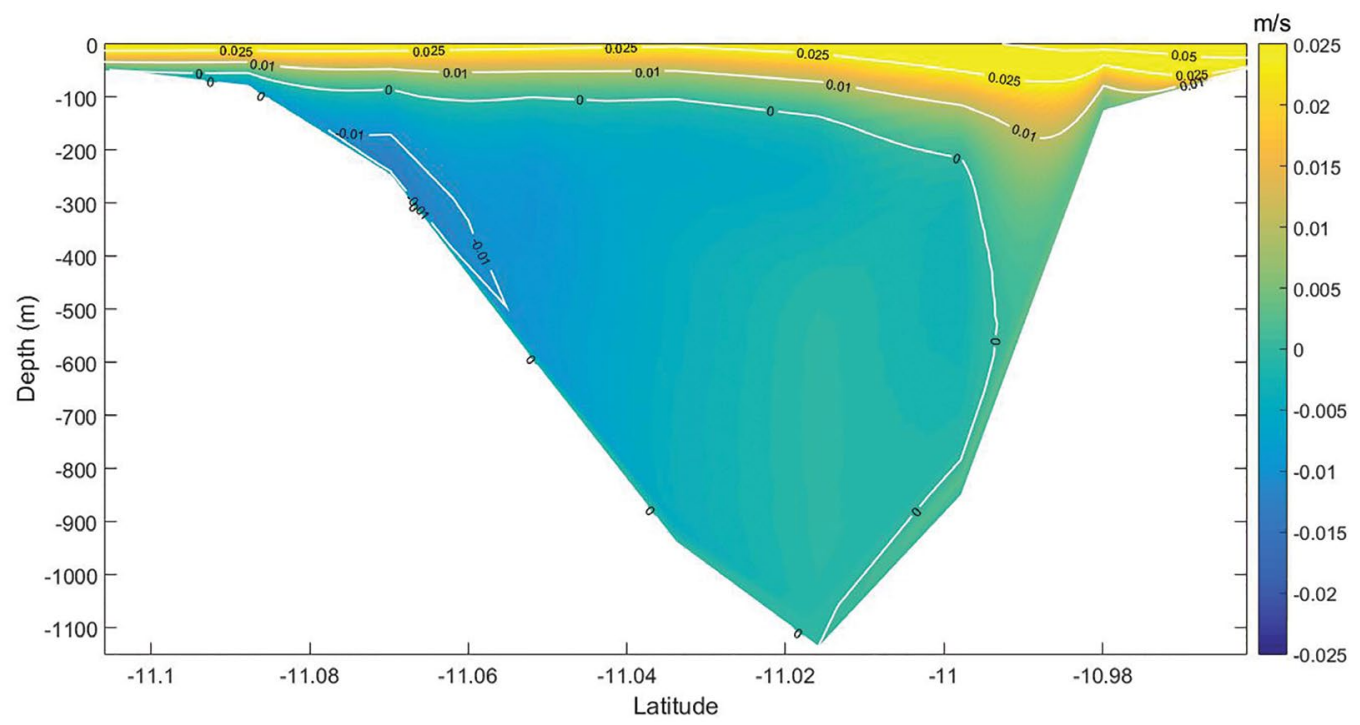

Figure 11. Velocity perpendicular to the vertical section of the canyon (positive values indicate subsidence, negative values indicate downward motion) for southeast simulation.

variability of the transport integrated every $50 \mathrm{~m}$ over the corresponding area shows a net flow towards the open ocean for all depths (Figure 14), being relatively strong near the surface, very weak between 50 and $200 \mathrm{~m}$ of depth, relatively strong between 250 and $750 \mathrm{~m}$ of depth, and almost null at depths of $800 \mathrm{~m}$ and deeper. Therefore, the NBU promotes a net transport of water from the canyon towards the open ocean, which creates a subsidence process at the upper face of the canyon.
When Northeast and East constant winds are introduced, the water mass exchange between the canyon and the open ocean changes. While for experiment NW the flow is towards the open ocean at all depths, for experiments C5 (Northeast winds) and C6 (East winds), the surface flow becomes slightly negative up to $100 \mathrm{~m}$ of depth, and the flow towards the open ocean is intensified between 100 and $500 \mathrm{~m}$. Experiments C5 and C6 show very similar results in terms of the observed values as well. For 


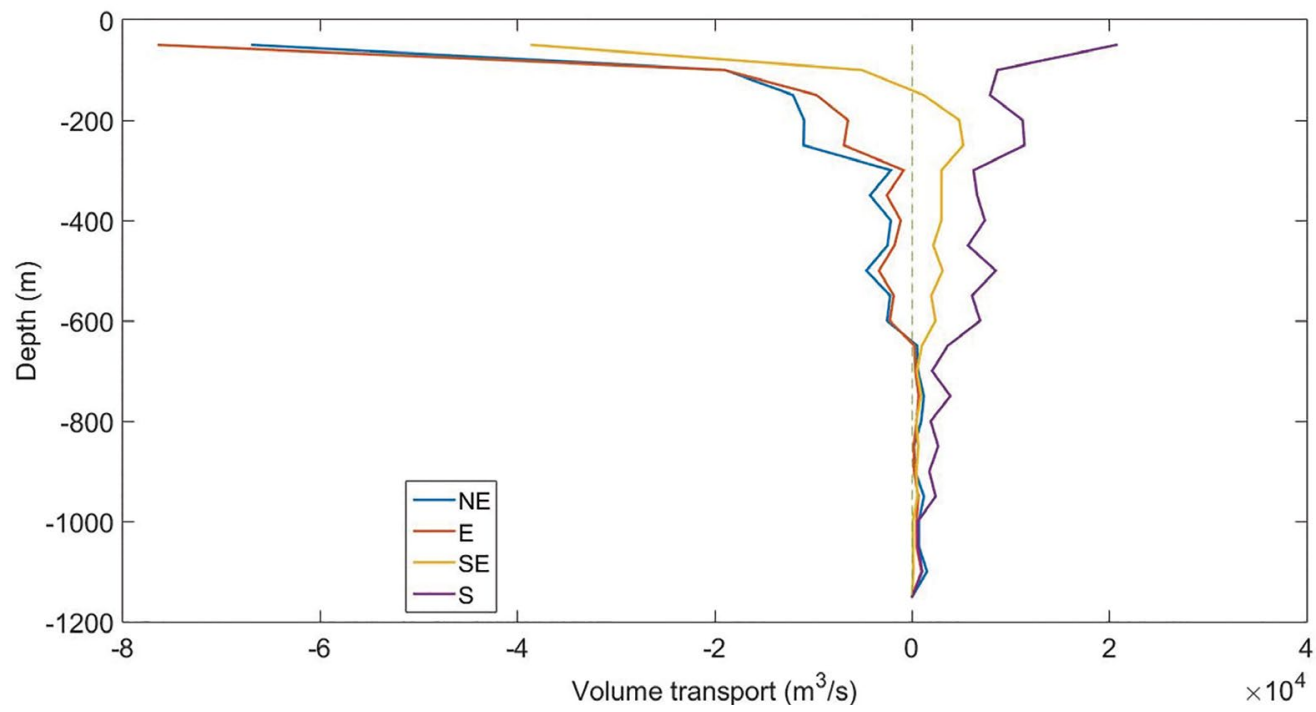

Figure 12. Volume flow perpendicular to the section of Japaratuba canyon (positive values indicate subsidence, negative values indicate upward motion), for NE, E, SE and S winds simulations and homogeneous temperature and salinity fields (experiments $\mathrm{C} 1$ to $\mathrm{C} 4$ ), integrated every $50 \mathrm{~m}$.

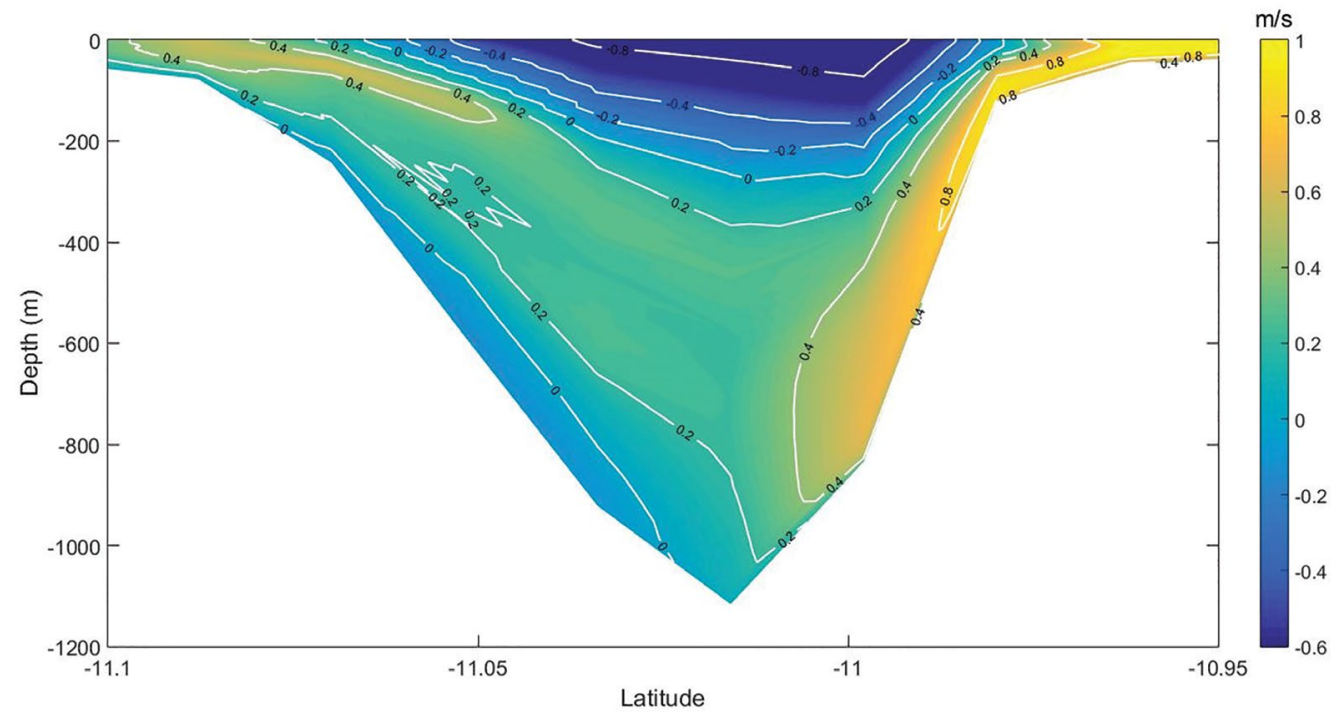

Figure 13. Velocity perpendicular to the vertical section of the canyon (positive values indicate subsidence, negative values indicate downward motion) for the simulation without wind (experiment NW).

experiment $\mathrm{C} 7$ (Southeast winds), the offshore transport is very close to what is observed in experiment NW. For experiment $\mathrm{C} 8$ (South winds), there is a strong intensification of the flow towards the open ocean up to $200 \mathrm{~m}$ of depth, and a weakening of it below that depth when compared to the NW experiment.

The net water mass transport between the canyon and the open ocean for experiments $\mathrm{C} 5$ to $\mathrm{C} 8$ and experiment NW is presented in Table 2. These results show that Northeast and East winds (experiments C5 and C6) enhances the exportation of water from the canyon to the open ocean, when compared to a scenario with no wind forcing (experiment NW), whilst winds from Southeast and South (experiments C7 and C8) act in the opposite direction, weakening the net water mass transport. In all simulations, however, the net water mass transport is positive, with water exiting the canyon towards the open ocean.

Experiment R1, with reanalysis winds and stratified temperature and salinity fields for March 2014, presents a net transport from the canyon towards the open ocean during all the time. There is, however, a strong temporal 


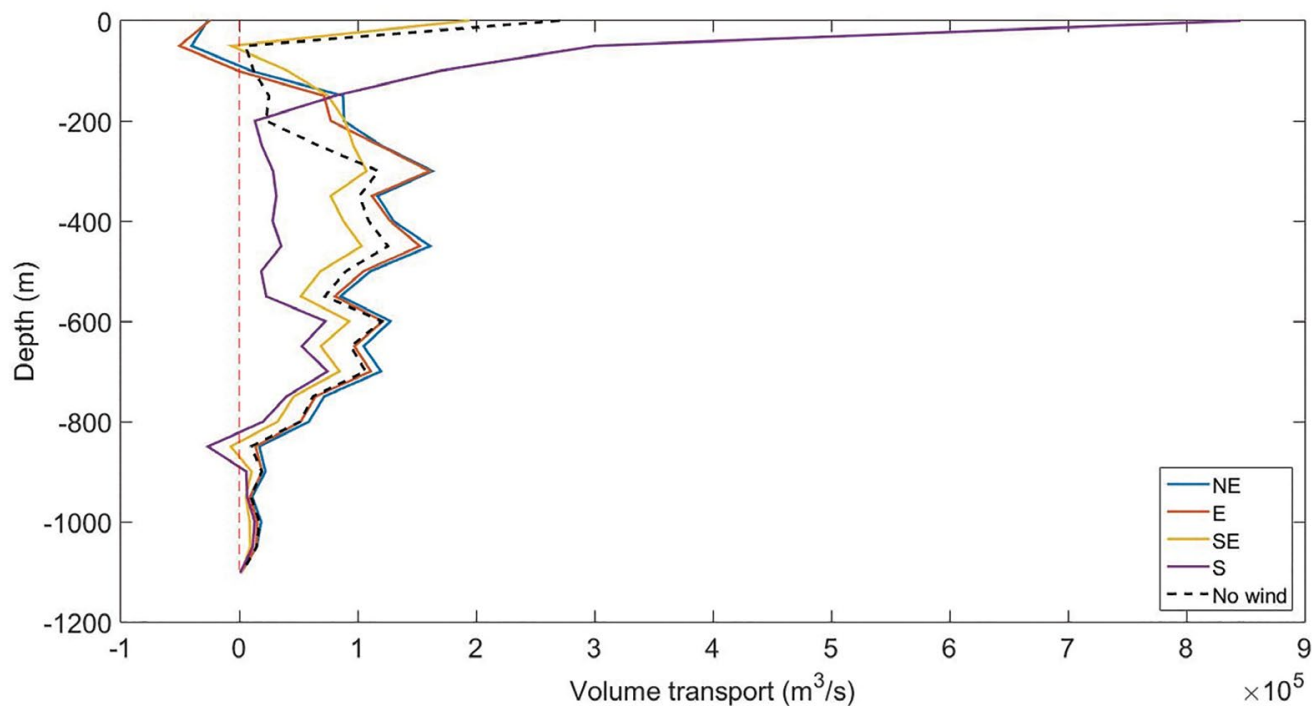

Figure 14. Volume flow perpendicular to the section of Japaratuba canyon (positive values indicate subsidence, negative values indicate upward motion), for NE, E, SE and $\mathrm{S}$ winds simulations (experiments $\mathrm{C} 5$ to $\mathrm{C} 8$ ) and without wind (experiment $\mathrm{NW}$ ) with stratified temperature and salinity fields, integrated every $50 \mathrm{~m}$.

Table 2. Transport of the water mass at integrated over the canyon cross section.

\begin{tabular}{lc}
\hline Experiment & Offshore net transport $\left(106 \mathrm{~m}^{3} \cdot \mathrm{s}^{-1}\right)$ \\
\hline $\mathrm{NW}$ & 1.26 \\
$\mathrm{C} 5$ & 1.60 \\
$\mathrm{C} 6$ & 1.48 \\
$\mathrm{C} 7$ & 1.15 \\
$\mathrm{C} 8$ & 1.02 \\
\hline
\end{tabular}

variability in this transport (Figure 15). During the period of transport decrease, between days 3 and 6 and days 10 to 16 , the winds are mainly from East and Southeast (incidence angles greater than $90^{\circ}$ ), while during the period of transport increase, between days 6 and 10, the winds are mainly from Northeast (incidence angles smaller than $90^{\circ}$ ). Experiment R2 (similar to R1, but for the month of July - Figure 16) presents a period with a net transport from the open ocean towards the canyon, from day 1 to day 11, and positive for the rest of the simulation. During the negative transport period, winds are mainly from Southeast. Finally, experiment R3 (similar to R1, but for the month of September - Figure 17) shows a positive net transport during all the simulation period, with some oscillations, but increasing in the average from the beginning until the end. The wind incidence angle are, mainly, from East and Southeast during this period.

\section{DISCUSSION}

Northeast and East winds alone, in homogeneous temperature and salinity fields, favor upward motion, whereas
Southeast and South winds, subsidence. The local observed winds (Figure 3 ) show that the most common wind varies from East to Southeast directions and, therefore, the wind forcing is capable of producing both vertical motions. For upward winds, the current over the continental shelf and near the slope are predominantly southwestward, reaching up to $0.20 \mathrm{~m} . \mathrm{s}^{-1}$, being more intense for Northeast winds. For subsidence winds, currents are basically in the opposite direction, reaching values up to $0.10 \mathrm{~m} \cdot \mathrm{s}^{-1}$.

Winds parallel to the coast are the most effective in enhancing subsidence and resurgence motion. It is also possible to classify that winds with incidence angle higher than $125^{\circ}$ in relation to the true North, for this region, favor subsidence in the Japaratuba canyon, while incidence angles smaller than $120^{\circ}$, resurgence motion. Similarly, the flow of the NBU promotes subsidence motion. As in other studies (Madron, 1994; Allen, 1996; Klinck, 1996; Granata et al., 1999; She and Klinck, 2000; Bosley et al., 2004; Jordi et al., 2005), the formation of closed vortices in the canyon is observed, both cyclonic, for upward winds, and anti-cyclonic, for subsidence winds, mainly near the surface.

The NBU, on the other hand, acts in the sense of producing subsidence motion at all depths. Therefore, there are some situations when the NBU and the winds force opposite motions, while one induces subsidence, the other could try to promote resurgence. As a net result of these forcings, usually predominates the action of the NBU, and the Japaratuba canyon is mainly an exporter of water to the open ocean. 

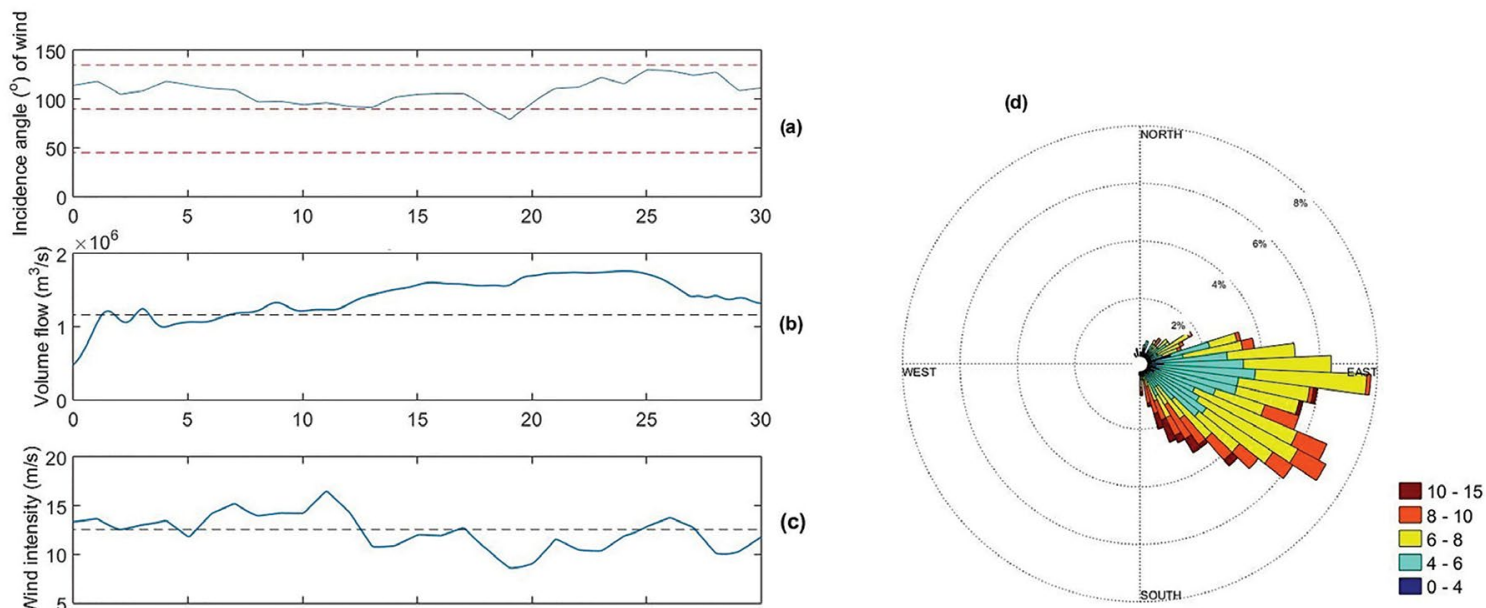

Figure 15. Incidence angle of average wind (a), Volume flow in the canyon section (b), intensity of average wind (c), and the wind rose (d), in the simulation for March 2014 (experiment R1).

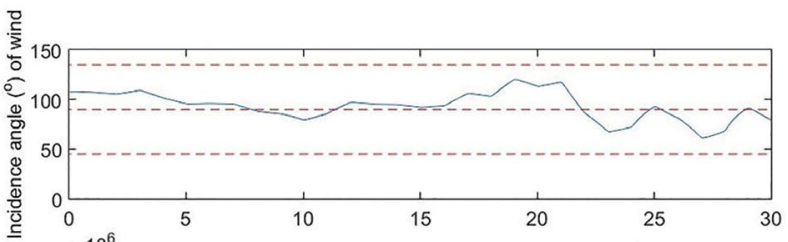

(a)

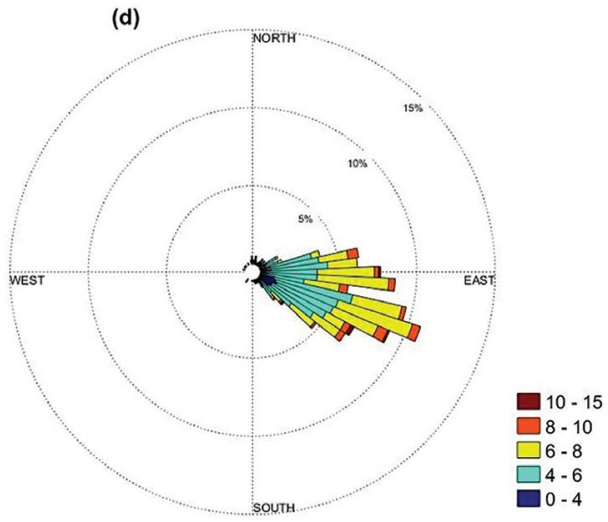

Figure 16. Incidence angle of average wind (a), Volume flow in the canyon section (b), intensity of average wind (c), and the wind rose (d), in the simulation for July 2014 (experiment R2).

Nevertheless, it is not possible to affirm that this canyon is always behaving in this sense. The sensitive experiments $\mathrm{C} 5$ to $\mathrm{C} 8$ show that the vertical structure of water exchange is considerably changed due to the wind action, promoting a net transport of water from the open ocean to the canyon near the surface. Even more striking is experiment R2, with winds from reanalysis, showing that, depending on the winds and the temperature and salinity structure, the net transport can be completely reversed, with water from the deep ocean entering the canyon. It seems that the wind intensity and direction plays a major role in this process and the sensitive experiments ( $\mathrm{C} 5$ to C8) could not capture a complete reversal of the transport because more intense winds were not applied, which is not the case of experiment R2. I any case, even when the net transport is positive (towards the open ocean), the wind is capable of promoting a substantial variability.

\section{CONCLUSION}

The present work has shown that the topography of the region (presence of the Japaratuba canyon) affects the circulation of the region and the volume flow between the open ocean and the continental shelf. It was shown that in all scenarios the circulation is preferably parallel to the coast (NE or SW direction, following the bathymetry), except in the canyon region, where cyclonic or anti-cyclonic 

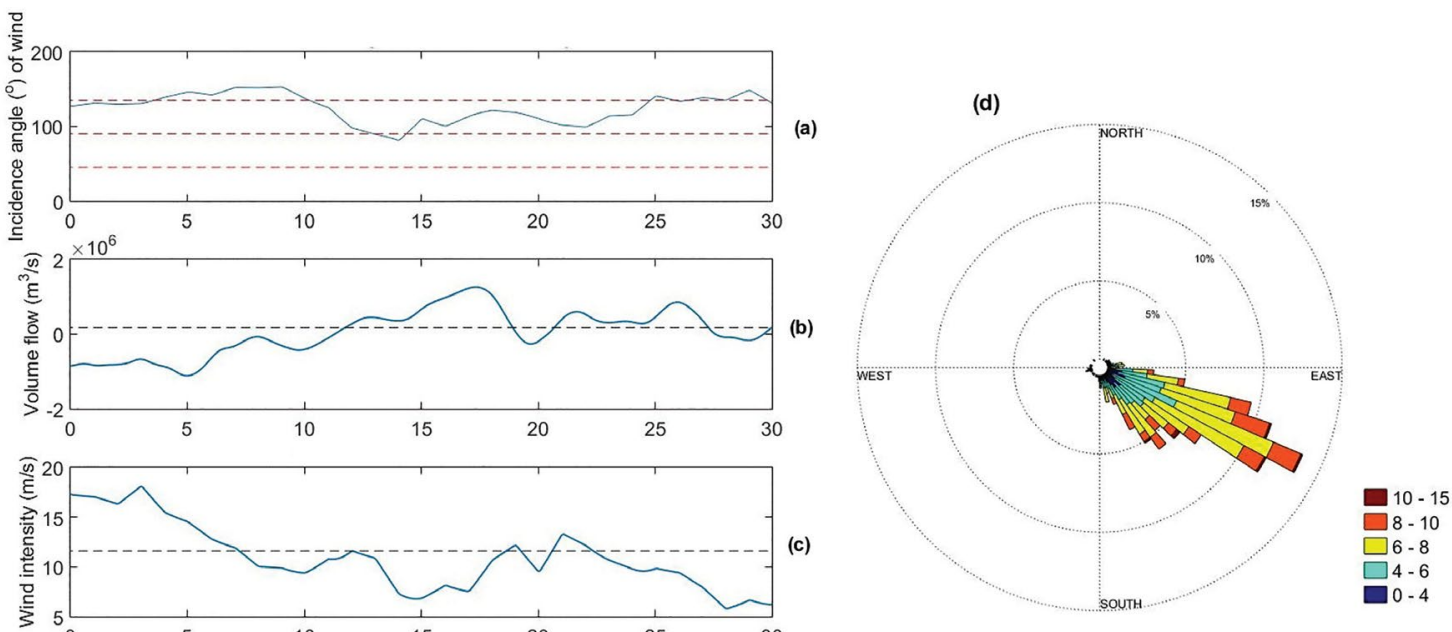

Figure 17. Incidence angle of average wind (a), Volume flow in the canyon section (b), intensity of average wind (c), and the wind rose (d), in the simulation for September 2014 (experiment R3).

circulation occurs throughout the entire canyon, or perpendicular to the coast. This motion within the canyon allows a volume flow that crosses isobaths in both directions.

The influence of the NBU, acting to transfer water from the canyon to the deep ocean, is more relevant than the wind action, that can promote motion in both directions. However, the circulation in the canyon, as well as the water mass exchange between the canyon and the deep ocean, cannot be analyzed by the effects of the NBU alone, not only in terms of the vertical structure, but also in terms of the net water mass exchange between these 2 compartments. Although the Japaratuba canyon seems to behave most of the time as a water export to the deep ocean, this flow can be reversed depending on the winds and the temperature and salinity structure. Also, the winds promote a stronger variability in the water mass exchange between the canyon and the deep ocean near the surface, but its influence can be noticed in all water column.

Other forcings, like the tides and the river discharge, were not analyzed in this work, but it is expected that their influence is very limited and not as important as the influence of the winds and the NBU. Previous simulations and data analysis performed by Parente (2016) show that the currents induced by these forcings are much smaller than the ones created by the wind forcing.

\section{REFERENCES}

AHUMADA-SEMPOAL, M. A., FLEXAS, M. M., BERNARDELLO, R., BAHAMON, N., CRUZADO, A. \& REYES-HERNÁNDEZ, C. 2015. Shelf-slope exchanges and particle dispersion in Blanes submarine canyon (NW Mediterranean Sea): A numerical study. Continental Shelf Research, 109, $35-45$.
ALLEN, S. E. 1996. Topographically Generated, Subinertial Flows within A Finite Length Canyon. Journal of Physical Oceanography, 26, 1608-1632.

ALLEN, S. E., VINDEIRINHO, C., THOMSON, R. E., FOREMAN, M. G. G. \& MACKAS, D. L. 2001. Physical and biological processes over a submarine canyon during an upwelling event. Canadian Journal of Fisheries and Aquatic Sciences, 58, 671-684.

ALLEN, S. E. \& MADRON, X. D. 2009. A review of the role of submarine canyons in deep-ocean exchange with the shelf. Ocean Science, 5, 607-620.

ARDHUIN, F., PINOT, J. M. \& TINTORÉ, J. 1999. Numerical study of the circulation in a steep canyon off the Catalan coast (western Mediterranean). Journal of Geophysical Research: Oceans, 104, 11115-11135.

BLUMBERG, A. F., KHAN, L. A. \& ST. JOHN, J. P. 1999. Three-Dimensional Hydrodynamic Model of New York Harbor Region. Journal of Hydraulic Engineering, 125, 799-816.

BLUMBERG, A. F. \& MELLOR, G. L. 1987. A Description of a Three-Dimensional Coastal Ocean Circulation Model. ThreeDimensional Coastal Ocean Models, 4, 1-16.

BOSLEY, K. L., LAVELLE, J. W., BRODEUR, R. D., WAKEFIELD, W. W., EMMETT, R. L., BAKER, E. T. \& REHMKE, K. M. 2004. Biological and physical processes in and around Astoria submarine Canyon, Oregon, USA. Journal of Marine Systems, 50, 21-37.

COUTINHO, P. N. 1976. Geologia marinha da plataforma continental Alagoas-Sergipe [Free teaching thesis]. Recife: Pernambuco Federal University.

FREELAND, H. J. \& DENMAN, K. L. 1982. A topographically controlled upwelling center off southern Vancouver Island. Journal of Marine Research, 40, 1069-1093.

GRANATA, T. C., VIDONDO, B., DUARTE, C. M., SATTA, M. P. \& GARCIA, M. 1999. Hydrodynamics and particle transport associated with a submarine canyon off Blanes (Spain), NW Mediterranean Sea. Continental Shelf Research, 19, 1249-1263. 
HAMILTON, P., SPEER, K., SNYDER, R., WIENDERS, N. \& LEBEN, R. R., 2015. Shelf break exchange events near the De Soto Canyon. Continental Shelf Research, 110, 25-38.

HICKEY, B., BAKER, E. \& KACHEL, N. 1986. Suspended particle movement in and around Quinault submarine canyon. Marine Geology, 71, 35-83.

HICKEY, B. M. 1997. The Response of a Steep-Sided, Narrow Canyon to Time-Variable Wind Forcing. Journal of Physical Oceanography, 27, 697-726.

JORDI, A., ORFILA, A., BASTERRETXEA, G. \& TINTORÉ, J. 2005. Shelf-slope exchanges by frontal variability in a steep submarine canyon. Progress in Oceanography, 66,120-141.

KLINCK, J. M. 1988. The influence of a narrow transverse canyon on initially geostrophic flow. Journal of Geophysical Research: Oceans, 93, 509-515.

KLINCK, J. M. 1996. Circulation near submarine canyons: A modeling study. Journal of Geophysical Research: Oceans, 101,1211-1223.

LELLOUCHE, J. M., LEGALLOUDEC, O., REGNIER, C., LEVIER, B., GREINIER, E. \& DREVILLON, M. 2016. For Global Sea Physical Analysis and Forecasting Product. 2.0. Product User Manual, Brussels, Copernicus Marine Environment Monitoring Service.

MADRON, X. D. 1994. Hydrography and nepheloid structures in the Grand-Rhône canyon. Continental Shelf Research, 14, 457-477.

PALANQUES, A., GARCÍA-LADONA, E., GOMIS, D., MARTÍN, J., MARCOS, M., PASCUAL, A., PUIG, P., GILI, J. M., EMELIANOV, M., MONSERRAT, S., GUILLÉN, J., TINTORÉ, J., SEGURA, M., JORDI, A., RUIZ, S., BASTERRETXEA, G., FONT, J., BLASCO, D. \& PAGĖS, F. 2005. General patterns of circulation, sediment fluxes and ecology of the Palamós (La Fonera) submarine canyon, northwestern Mediterranean. Progress in Oceanography, 66, 89-119.

PARENTE, F. T. F. 2016. Hidrodinâmica da Plataforma Continental da bacia Sergipe-Alagoas [Master's dissertation]. São Paulo: University of São Paulo.
REID, R. O. \& BODINE, B. R. 1968. Numerical model for storm surges in Galveston Bay. Journal of the Waterways and Harbors Division, 94, 33-58.

RENNIE, S. J., PATTIARATCHI, C. B. \& MCCAULEY, R. D. 2009. Numerical simulation of the circulation within the Perth Submarine Canyon, Western Australia. Continental Shelf Research, 29, 2020-2036.

SAHA, S., MOORTHI, S., WU, X., WANG, J., NADIGA, S., TRIPP, P., BEHRINGER, D., HOU, Y., CHUANG, H., IREDELL, M., EK, M., MENG, J., YANG, R., MENDEZ, M. P., VAN DEN DOOL, H., ZHANG, Q., WANG, W., CHEN, M. \& BECKER, E. 2014. The NCEP Climate Forecast System Version 2. Journal of Climate, 27, 2185-2208.

SHE, J. \& KLINCK, J. M. 2000. Flow near submarine canyons driven by constant winds. Journal of Geophysical Research: Oceans, 105, 28671-28694.

SILVEIRA, I. C., MIRANDA, L. B. \& BROWN, W. S. 1994. On the origins of the North Brazil Current. Journal of Geophysical Research: Oceans, 99, 22501-22512.

SKLIRIS, N., HECQ, J. H. \& DJENIDI, S. 2002. Water fluxes at an ocean margin in the presence of a submarine canyon. Journal of Marine Systems, 32, 239-251.

SKLIRIS, N., LACROIX, G. \& DJENIDI, S. 2004. Effects of extreme meteorological conditions on coastal dynamics near a submarine canyon. Continental Shelf Research, 24, 10331045 .

SOBARZO, M., FIGUEROA, M. \& DJURFELDT, L. 2001. Upwelling of subsurface water into the rim of the Biobio submarine canyon as a response to surface winds. Continental Shelf Research, 21, 279-299.

SONG, Y. T. \& CHAO, Y. 2004. A theoretical study of topographic effects on coastal upwelling and cross-shore exchange. Ocean Modelling, 6, 151-176.

STRAMMA, L., FISCHER, J. \& REPPIN, J. 1995. The North Brazil Undercurrent. Deep Sea Research Part I: Oceanographic Research Papers, 42, 773-795.

SUMMERHAYES, C. P., FAINSTEIN, R. \& ELLIS, J. P. 1976. Continental margin off Sergipe and Alagoas, northeastern Brazil: A reconnaissance geophysical study of morphology and structure. Marine Geology, 20, 345-361. 